\title{
The Study on the Evaluation of Regional Brand's Innovation Capacity----Insights from Manufacturing Companies in Jiangmen of China
}

\author{
Liu He $^{1}$ Hong Ying Wu ${ }^{1}$ ShuJin Lin ${ }^{1}$ Chun Xiao ${ }^{1,2}$ Jingyi Wang $^{3}$ Zheng He $^{1}$ Qing He $^{4}$ \\ ${ }^{1}$ Economics \& Management School, Wu Yi University ,Jiangmen, P.R,China,529020; \\ ${ }^{2}$ Xinhui Rural Commercial Bank, Jiang Men,P.R, China,529100; \\ ${ }^{3}$ School of Business Administration,Guangdong University of Finance \& Economics, Guangzhou,P.R, \\ China,510320; \\ ${ }^{4}$ Public Health and Management Institute,Chongqing Medical University,Chongqing,P.R.China, \\ 400016.
}

\begin{abstract}
Drawing on transformation and upgrading of advanced equipment manufacturing industry, this paper proposed an approach of how to evaluate the performance of advanced equipment manufacturing companies. Factor Analysis is adopted to analyze the innovation of reginal company. After analyzing the overall scores and ranks of the innovation capacity advanced equipment companies, we conclude that Transport Equipment Manufacturing industry has prominent advantages and potentials in contributing Jiangmen's development and the key of creating Jiangmen's reginal brands lies in developing and maintaining advantages of Transport Equipment Manufacturing industry. The results provides important theoretical and empirical implications to Jiangmen's industry transforamtion and upgrading.
\end{abstract}

Keywords: Regional Brand; Industry's Innovation Capacity; advanced equipment and manufacture; Evaluation index system; Factor analysis; Jiangmen of China

\section{Overview}

Regional brand industry is the most important industry of the region. Regional comprehensive strength to a large extent depends on regional industry brand ranking of the region core of the comprehensive competitiveness.Advanced equipment manufacturing industry is the pillar industry of our country economic development, the foundation of industrial development, a sign of the regional industrial level and the core of the regional brand competitive advantage. As a member of the "pearl river delta" region, Jiangmen in the plan for the twelfth five-year national economic and social development compendium in Jiangmen (herein after referred to as the "five-year plan"), which clearly put forward form the economic structure of taking advanced manufacturing industry as the core and modern service industry developing coordinatedly.

On the basis of advanced transformation and upgrading of equipment manufacture, this paper built the index system of the evaluation of advanced equipment manufacturing industry brand innovation capacity, carries to analyze to the advanced industry's brand of equipment manufacture of Jiangmen, and provided theoretical guidance and decision-making basis for creating the regional brand in Jiangmen. 
2.Construction of evaluation index system 0 $n$ the innovation capacity of regional brand

In the line with principles of science, rationality, comprehensiveness, systemic and operability,this text has chosen the evaluation index system including3classes and 20 indexes from economic creativity,capacity of scientific and technological research and development, environmental protection of resources.Index A to reflect the economic capacity to create, including 7 indicators: total industrial output value, industrial added value, industrial added value rate, the contribution rate of total assets, total assets profit rate, labor productivity and cost profit rate.Index $\mathrm{B}$ to reflect the science and technology R\&D capacity,including 6 indicators:Per capita R\&D funds, R\&D fund industry accounted for the proportion of the total investment, investment funds, the annual R\&D new product output value, output value of new products and investment in fixed assets.Index $\mathrm{C}$ to reflect the environment and resources protection capacity,including7 indicators:Comprehensive energy consumption, million yuan output value of energy consumption, energy-saving rate, coal consumption, fuel consumption and power consumption. Specific indicators are shown in Table 1.

Table 1 evaluation index system of regional industry brand

\begin{tabular}{|c|c|c|c|}
\hline First-level indicators & Secondary indexes & Secondary index code & $\begin{array}{l}\text { Unit of secondary } \\
\text { indicators }\end{array}$ \\
\hline \multirow{7}{*}{$\begin{array}{l}\text { Economic creation } \\
\text { capacity }(\mathrm{A})\end{array}$} & $\begin{array}{l}\text { Gross value of industrial } \\
\text { output }\end{array}$ & A1 & Hundred million \\
\hline & $\begin{array}{l}\text { The added value of } \\
\text { industrial }\end{array}$ & $\mathrm{A} 2$ & Hundred million \\
\hline & $\begin{array}{c}\text { Industrial added value } \\
\text { rate }\end{array}$ & A3 & $\%$ \\
\hline & Total assets contribution & A4 & $\%$ \\
\hline & $\begin{array}{l}\text { Total assets profit } \\
\text { margins }\end{array}$ & A5 & $\%$ \\
\hline & $\begin{array}{l}\text { The overall Labour } \\
\text { productivity }\end{array}$ & A6 & $\begin{array}{c}\text { Yuan per person each } \\
\text { year }\end{array}$ \\
\hline & The cost profit margins & A7 & $\%$ \\
\hline \multirow{6}{*}{ R\&Dcapacity（B） } & R\&D spending per capita & B1 & Yuan per person \\
\hline & $\begin{array}{c}\mathrm{R} \& \mathrm{D} \text { expenditure } \\
\text { intensity }\end{array}$ & B2 & $\%$ \\
\hline & $\begin{array}{l}\text { The annual R\&D } \\
\text { spending }\end{array}$ & B3 & Ten thousand \\
\hline & New products output & B4 & Hundred million \\
\hline & $\begin{array}{l}\text { New products output } \\
\text { ratio }\end{array}$ & B5 & $\%$ \\
\hline & Fixed assets investment. & B6 & Ten thousand \\
\hline \multirow{2}{*}{$\begin{array}{l}\text { Environment and } \\
\text { resources protection } \\
\text { (C) }\end{array}$} & $\begin{array}{l}\text { Comprehensive energy } \\
\text { consumption }\end{array}$ & $\mathrm{C} 1$ & Tce \\
\hline & $\begin{array}{l}\text { Ten thousand yuan output } \\
\text { value of energy } \\
\text { consumption }\end{array}$ & $\mathrm{C} 2$ & Tce/ten thousand \\
\hline
\end{tabular}




$\begin{array}{ccc}\text { Energy saving rate } & \mathrm{C} 3 & \% \\ \text { Raw coal consumption } & \mathrm{C} 4 & \text { Ton } \\ \text { Fuel consumption } & \mathrm{C} 5 & \text { Ton } \\ \text { The power consumption } & \mathrm{C} 6 & \text { Million kilowatt hour }\end{array}$

3.Empirical analysis of the key industry of city branding in Jiangmen

\subsection{Data collection}

For the classification of the advanced equipment manufacturing industry, adopt classification of GB/T4754-2002which namely to divide7 sub trades into equipment manufacture in this text,and make research on the regional brand innovation capacity of the equipment manufacturing industry. Regard 7 sub trades of advanced equipment manufacturer as the system frame of the evaluation index, collect the initial data of 7 sub trades of equipment manufacture of Jiangmen.

\subsection{Factor Analysis}

According to the initial data listed in Table 2, using statistical analysis software SPSS19.0,analysis Jiangmen the equipment manufacturing industry of regional brand innovation capacity for factor with seven sample sizes, 19 variables.

\subsubsection{Determine the number of common factor}

Usually public factor is selected according to the principle of characteristic roots is greater than 1 , in this paper we elected to four public factor, the cumulative variance contribution rate reached $93.91 \%$, is said that this four common factor include the basic information of the 19 variables, that is to say, we can be through the four common factor to explain all the original variable contains all the information. The results are shown in Table 2 .

Table 2 Total Variance Explained

\begin{tabular}{ccccccc}
\hline Componen & \multicolumn{3}{c}{ Initial Eigenvalues } & \multicolumn{3}{c}{$\begin{array}{c}\text { Extraction Sums of } \\
\text { Squared Loadings }\end{array}$} \\
\hline $\mathrm{t}$ & Total & \% of Variance & Cumulative \% & Total & \% of Variance & Cumulative \% \\
\hline 1 & 8.849 & 46.572 & 46.572 & 8.849 & 46.572 & 46.572 \\
2 & 5.461 & 28.741 & 75.313 & 5.461 & 28.741 & 75.313 \\
3 & 2.111 & 11.111 & 86.424 & 2.111 & 11.111 & 86.424 \\
4 & 1.423 & 7.487 & 93.911 & 1.423 & 7.487 & 93.911 \\
5 & .736 & 3.874 & 97.785 & & & \\
6 & .421 & 2.215 & 100.000 & & & \\
7 & $5.953 \mathrm{E}-16$ & $3.133 \mathrm{E}-15$ & 100.000 & & & \\
8 & $4.354 \mathrm{E}-16$ & $2.291 \mathrm{E}-15$ & 100.000 & & & \\
9 & $3.835 \mathrm{E}-16$ & $2.018 \mathrm{E}-15$ & 100.000 & & & \\
10 & $2.365 \mathrm{E}-16$ & $1.245 \mathrm{E}-15$ & 100.000 & & & \\
11 & $1.718 \mathrm{E}-16$ & $9.043 \mathrm{E}-16$ & 100.000 & & & \\
12 & $8.239 \mathrm{E}-17$ & $4.336 \mathrm{E}-16$ & 100.000 & & & \\
13 & $-2.370 \mathrm{E}-18$ & $-1.247 \mathrm{E}-17$ & 100.000 & & &
\end{tabular}




$\begin{array}{llll}14 & -6.677 \mathrm{E}-17 & -3.514 \mathrm{E}-16 & 100.000 \\ 15 & -1.020 \mathrm{E}-16 & -5.370 \mathrm{E}-16 & 100.000 \\ 16 & -2.738 \mathrm{E}-16 & -1.441 \mathrm{E}-15 & 100.000 \\ 17 & -3.347 \mathrm{E}-16 & -1.762 \mathrm{E}-15 & 100.000 \\ 18 & -3.494 \mathrm{E}-16 & -1.839 \mathrm{E}-15 & 100.000 \\ 19 & -5.128 \mathrm{E}-16 & -2.699 \mathrm{E}-15 & 100.000\end{array}$

\begin{tabular}{|c|c|c|}
\hline $\begin{array}{l}\text {.2.2The factor loading } \\
\text { omponent score coefficient }\end{array}$ & matrix & $\begin{array}{l}\text { Rotate the initial factor loading matrix, the } \\
\text { component score coefficient, specific results } \\
\text { are showed in table } 3 \text {. }\end{array}$ \\
\hline
\end{tabular}

Table3 Component Score Coefficient Matrix

\begin{tabular}{lcccc}
\hline & \multicolumn{4}{c}{ Component } \\
\cline { 2 - 5 } A1 & 1 & 2 & 3 & 4 \\
\cline { 2 - 5 } A2 & .119 & .008 & .070 & .035 \\
A3 & .125 & -.002 & .060 & .031 \\
A4 & -.005 & -.088 & -.082 & -.189 \\
A5 & .010 & .029 & .072 & .427 \\
A6 & -.015 & .093 & .057 & .283 \\
A7 & .018 & .128 & .025 & .033 \\
B1 & -.075 & .157 & .024 & .042 \\
B2 & -.058 & .169 & -.005 & -.106 \\
B3 & -.099 & .123 & -.007 & -.037 \\
B4 & -.016 & .165 & .073 & -.145 \\
B5 & .106 & .075 & -.074 & -.144 \\
B6 & .045 & .116 & -.129 & -.118 \\
C1 & .115 & -.069 & .082 & .220 \\
C2 & -.077 & .030 & .498 & .116 \\
C3 & -.060 & .008 & -.297 & .090 \\
C4 & .043 & .103 & .181 & -.424 \\
C5 & .155 & -.004 & -.239 & -.120 \\
C6 & .163 & -.034 & -.132 & -.081 \\
A & .142 & -.048 & -.022 & -.027 \\
\hline
\end{tabular}

As known as the table 3 above, the final industrial added value of gross output A1, The formula of factor score are as follows:

$H 1=0.119 .41+0.125 A 2-0.005 A B+0.010 .44+\cdot \cdot 0.163 C 5+0.142 C 6 ;$; (1)

added value of industrialA2, New products $H 2=0.008 A 1-0.002 A 2-0.088 A B+0.029 A 4+\cdot-0.034 C 5-0.048 C 6,(2)$

$H 3=0.070 .1+0.060 . A 2-0.022 A 3+0.022 A+-0.13005-0.02206,(3)$

$H 4=0.035 A 1+0.031 A 2-0.189 A 3+0.427 A 4+\cdot-0.081 C 5-0.027 C 6(4)$

outputB4, fixed assets investment. B6, Raw coal consumption $\mathrm{C} 4$, fuel consumptionC5 The power consumptionC6, these indicators of H1 embodies the comprehensive index of production and energy of the equipment manufacturing industry, we called the comprehensive factor; $\mathrm{H} 2$ is the second factor,

$\mathrm{H} 1$ is the first factor, on behalf of the 
represents the total assets profit marginsA5, The overall Labor productivity A6, The cost profit margins A7, R\&D spending per capita B1, R\&D expenditure intensity B2, The annual R\&D spending B3, New products output ratio $\mathrm{B} 5$, these indicators of $\mathrm{H} 2$ embodies the Economic profitability of the equipment manufacturing industry and $R \& D$ profitability indicators such as economy, we can called the profit factor; H3 said the third factor, better represents the Comprehensive energy consumptionC1, so we can called energy consumption factor; H4 said the fourth factor, better represents the total assets contributionA4,we can called assets contribution factor; The other three indicators: Industrial added value rate $\mathrm{A} 3$, Ten thousand yuan output value of energy consumption C2,Energy saving rate C3, Has been dropped

\subsubsection{The regional brand innovation capacity assessment scores}

According to table 3 after rotating each variance and contribution ratio of the common factor to calculate for each common factor weight, calculating formula is $\alpha_{i}=\beta_{i} / \sum_{1}^{4} \beta_{i}$, $\alpha_{i}$ is $i$ The weights of common factor, ${ }^{\beta_{i}}$ is $i$ The eigenvalues of the main factors. According to the weight of factor score coefficient function and common factor, can construct the evaluation model. Industrial upgrading assessment model as follows:

$$
\begin{aligned}
& H=\alpha_{1} H 1+\alpha_{2} H 2+\alpha_{3} H 3+\alpha_{4} H 4 \\
& =40.37 H 1+37.85 H 2+12.20 H 3+9.58 H 4
\end{aligned}
$$

Which model of $\mathrm{H} 1, \mathrm{H} 2, \mathrm{H} 3$ and $\mathrm{H} 4$ are the factor score of each common factor. $\mathrm{H}$ is the composite scores. Using the above industrial upgrading assessment model, which can be further calculated the evaluation scores and comprehensive scores and rankings of the equipment manufacturing industry in Jiangmen.

The results are shown in table 4 .

\begin{tabular}{|c|c|c|c|c|c|c|c|c|c|c|c|}
\hline \multirow{8}{*}{ Industry } & \multicolumn{7}{|c|}{ Common factor score } & \multicolumn{2}{|c|}{$\begin{array}{c}\text { Composite } \\
\text { scores }\end{array}$} & \multicolumn{2}{|c|}{$\begin{array}{c}\text { centesimal } \\
\text { system }\end{array}$} \\
\hline & \multirow{7}{*}{$\mathrm{H} 1$} & \multirow{7}{*}{$\begin{array}{c}\mathrm{Ra} \\
\mathrm{nk} \\
\text { in } \\
\mathrm{g}\end{array}$} & \multirow{7}{*}{$\mathrm{H} 2$} & $\mathrm{R}$ & \multirow{7}{*}{$\mathrm{H} 3$} & $\mathrm{R}$ & \multirow{7}{*}{$\mathrm{H} 4$} & $\mathrm{R}$ & & \multirow{7}{*}{ score } & \multirow{7}{*}{$\begin{array}{c}\text { Ran } \\
\text { kin } \\
\mathrm{g}\end{array}$} \\
\hline & & & & $\mathrm{a}$ & & $\mathrm{a}$ & & $\mathrm{a}$ & & & \\
\hline & & & & $\mathrm{n}$ & & $\mathrm{n}$ & & $\mathrm{n}$ & & & \\
\hline & & & & $\mathrm{k}$ & & $\mathrm{k}$ & & $\mathrm{k}$ & & & \\
\hline & & & & $\mathrm{i}$ & & $\mathrm{i}$ & & $\mathrm{i}$ & & & \\
\hline & & & & $\mathrm{n}$ & & $\mathrm{n}$ & & $\mathrm{n}$ & & & \\
\hline & & & & $\mathrm{g}$ & & $\mathrm{g}$ & & $\mathrm{g}$ & & & \\
\hline $\begin{array}{c}\text { Metal product } \\
\text { industry }\end{array}$ & $\begin{array}{c}2.03 \\
08\end{array}$ & 1 & -0.62905 & 6 & -0.52434 & 6 & -0.14882 & 4 & 50.35 & 78.45 & 2 \\
\hline $\begin{array}{c}\text { General } \\
\text { equipment } \\
\text { manufacturing }\end{array}$ & $\begin{array}{c}-0.56 \\
777\end{array}$ & 5 & -0.13169 & 3 & -1.53966 & 7 & 1.3897 & 1 & -33.38 & 26.06 & 5 \\
\hline
\end{tabular}

Table 4 evaluation factor scores and ranking 


\begin{tabular}{|c|c|c|c|c|c|c|c|c|c|c|c|}
\hline $\begin{array}{l}\text { Special equipment } \\
\text { manufacturing }\end{array}$ & $\begin{array}{c}-0.91 \\
026\end{array}$ & 7 & 0.1447 & 2 & 0.1044 & 2 & 0.0450 & 3 & -29.57 & 28.45 & 4 \\
\hline $\begin{array}{c}\text { Transportation } \\
\text { equipment } \\
\text { manufacturing } \\
\text { industry }\end{array}$ & $\begin{array}{l}0.26 \\
626\end{array}$ & 2 & 2.1231 & 1 & -0.10172 & 5 & -0.52776 & 5 & 84.81 & 100 & 1 \\
\hline $\begin{array}{c}\text { Electrical } \\
\text { machinery and } \\
\text { equipment } \\
\text { manufacturing }\end{array}$ & $\begin{array}{c}0.19 \\
26\end{array}$ & 3 & -0.14174 & 4 & 1.78298 & 1 & 1.2907 & 2 & 36.53 & 69.8 & 3 \\
\hline $\begin{array}{l}\text { Communication } \\
\text { equipment, } \\
\text { computers and } \\
\text { other equipment } \\
\text { manufacturing }\end{array}$ & $\begin{array}{c}-0.27 \\
665\end{array}$ & 4 & -0.45176 & 5 & 0.3795 & 3 & -1.05102 & 7 & -33.71 & 25.86 & 6 \\
\hline $\begin{array}{l}\text { Instrumentation } \\
\text { and cultural, } \\
\text { office machinery } \\
\text { manufacturing }\end{array}$ & $\begin{array}{c}-0.73 \\
504\end{array}$ & 6 & -0.91349 & 7 & -0.10116 & 4 & -0.99779 & 6 & -75.04 & 0 & 7 \\
\hline
\end{tabular}

4.The results of brand innovation capacity of industry in Jiangmen

According to the score of each public factor that the industry brand creativity of the advanced equipment manufacture of Jiangmen appraises,it can be concluded that:First, the metal products industry has significant strength in the comprehensive factors (production,energy);Second, the manufacturing industry of the facilities for transport and communication has absolute advantages in the profit-making respect (profit, R\&D,etc.) of the economy; Third, the manufacturing industry of the electric machinery and equipment does very well in energy consumption (the volume of consumption of comprehensive energy); Fourth, general equipment manufacturing industry, electric machinery and equipment manufacturing industry in a leading position in the capital contribution (contribution rate of total assets); Fifth, manufacturing industry of the dedicated device and communication equipment, computer and other apparatuses manufacturing industry do not have any advantage in Jiangmen; Sixth, general equipment manufacturing industry and special equipment manufacturing industry which are the most capable of representing equipment manufacturing industry level still much room for development in Jiangmen.

Meanwhile, according to the comprehensive evaluation scores and rankings on the advanced industrial upgrading of equipment manufacture in Jiangmen, we can conclude that manufacturing industry of facilities for transport and communication is the advantage industry in the equipment manufacturing industry in Jiangmen. Metal products industry,electric machinery and equipment manufacturing industry are developing. Special equipment manufacturing industry, general equipment manufacturing industry, communications equipment, computers and other equipment manufacturing industry are in the initial stage of development. Instrumentation and culture, office machinery manufacturing is inferior sub-sectors. 
Therefore, we can conclude that creating a breakthrough of the regional brand of Jiangmen is transportation equipment manufacturing. Transportation equipment manufacturing industry in Jiangmen has a potential for development. Therefore, the key to creating industry brand in Jiangmen City is the priority of the development of the transportation industry.

Transportation equipment manufacturing industry in Jiangmen city has a larger scale, such as motorcycle production accounted for $15 \%$ of the national container, auto parts, ship manufacturing have higher visibility. 2010, CSR project bring new opportunities for Jiangmen transportation equipment manufacturing industry, in order to grasp the opportunity, wuyi university has established rail transit comprehensive laboratory, the development support the industry-universityresearch cooperation in Jiangmen city, makes the transportation equipment manufacturing into Jiangmen city brand, and promoting the development of transportation equipment manufacturing industry in Jiangmen city.

In the process of creating the regional brand, a unified planning is needed, Firstly, by the government. Government to make up the solution transportation equipment manufacturing industry, promoting its rapid development, and use the government's influence, promoting transportation equipment manufacturing industry on this "business card". Secondly, relying on schools to train professional talents. Industrial development cannot leave the talents, therefore, the development of Jiangmen transportation equipment manufacturing has to rely on colleges, to train professional talents to support the industry development. Thirdly, the establishment of research and development platform, provide technology support. Jiangmen also needs to increase investment in research and development platform, provide technology support for the transportation equipment manufacturing industry.

By priority to the development of the transportation equipment manufacturing, build strong transportation equipment manufacturing, make it become Jiangmen regional brand which is well-known in domestic and foreign. And the development of a regional brand, also can drive the industry's further development, promote economic and social prosperity. This also is the result we want.

\section{Acknowledgement:}

This research was financially supported by the National Natural Science Foundation of China(NSFC)(71272243;71202099;71172164), the Basic Research Foundation in Social Sciences \& Humanities of Ministry of Education of China (12YJA630038), and the Natural Science Foundation of Guangdong Province, China (S20110100008552).

\section{References}

[1]Chesbrough .Business Model Innovation: it 's not just about Technology Anymore [J] . Strat egy \& Leadership.2007, 35(6) : 12- 171.

[2]Ern st D \& Kim L1 Global Product ion Network s, Kn ow ledge Diffusion, and Local capacity Format ion $[\mathrm{J}]$. Research Policy 1 2002, 31( 8- 9) : 1417- 14291

[3]Hans en K L \& Ru sh H1 Hot spot s in Complex Product Systems: Emerging Issues in Innovation Management [J] .Technovation , 1998, 18( 8- 9) : 555- 5611

[4]Shi Y, Fl eet D \& Gregory M1 Global Manufacturing Virtual Network (GMVN) : A Revisit ing of the Concept after three Years Fieldwork[J] . Journal of Syst ems Science and Syst ems Engineering, 2003, 12(4) : 432- 4481 [5]Humphrey J \& Schmitz H. Govern ance and Upgrading:Linking Industrial $\mathrm{C}$ lust er an $\mathrm{d}$ Global Value Chain Research[Z] . IDS Working Paper No1 1201 2000, Bright on: Institute of Development Studies , University of Sussex. 